\title{
LEGAL CLINICS AS AN IMPORTANT ELEMENT OF HUMAN RIGHT FOR FREE LEGAL AID
}

CLÍNICAS DE DERECHO COMO UN ELEMENTO IMPORTANTE EN LA DEFENSA GRATUITA DE LOS DERECHOS HUMANOS

\section{Serhii Kivalov*}

\begin{abstract}
Nowadays, legal clinics exist in almost every country in the world. The article examines the legal status of legal clinics in Ukraine to properly ensure the human right to legal aid. The author emphasizes that legal clinics are an important element of the legal aid institute. Accordingly, there is an urgent need to regulate the legal status of legal clinics, since in this way the state fulfills its obligation to guarantee the constitutional right of every person to receive legal aid. Even though legal clinics perform important social tasks, regulatory regulation of their activity is carried out only at the level of acts of the Ministry of Education and Science of Ukraine. All attempts to consolidate the legal status of legal clinics at the level of the law-for example, the Law "On Free Legal Aid" of June 2, 2011-remain unrealized. The author states that the issue of improving the legal regulation of relations involving legal clinics should be resolved in the near future. Moreover, the Verkhovna Rada (Ukrainain Parlament) has recently started reforming its legislation in the field of advocacy. Therefore, there is a chance that the discriminatory norm of the Constitution regarding the lawyer's monopoly on representation in court will be abolished. Thus, this will open the way to improving the status of legal clinics, as employees of such
\end{abstract}

\footnotetext{
* Doctor of Legal Science. Academician full member of the National Academy of Law of Ukraine and National Academy of Pedagogical Sciences of Ukraine. Head of the Southern Regional Center National Academy of Law Sciences of Ukraine. Honored Lawyer of Ukraine. President of the National University "Odessa Law Academy" (Ukraine) and Professor of Department of administrative and financial law at the same institution. Researcher ID AAG-7107-2019. Orcid: 0000-0002-4651-1805. kivalov.academy@ onua.edu.ua
} 
institutions will have the opportunity, in addition to legal advice, to represent their clients in court.

Keywords: Human Rights, Legal Aid, Legal Clinic, Primary Legal Aid, Pro Bono

Resumen: Actualmente existen clínicas de derecho en casi todo país del mundo. Este artículo examina el estado legal de estas clínicas en Ucrania, a fin de asegurar el derecho humano a la defensa legal. El autor destaca que las clínicas de derecho son un importante elemento institucional de la defensa legal. En consecuencia, existe una urgente necesidad de regularlas, para así poder cumplir con la obligación de garantizar del derecho constitucional de toda persona a recibir este tipo de defensa. Aunque las clínicas de derecho llevan a cabo un importante rol social, la regulación reglamentaria de su actividad se lleva a cabo solo a nivel de actos del Ministerio de Educación y Ciencia ucraniano. Todos los esfuerzos de consolidar un estatuto legal de estas clínicas - por ejemplo, con la Ley sobre la defensa jurídica gratuita de 2 de junio de 2011- no han logrado culminar. Sobre todo, el Verkhovna Rada (el Parlamento ucraniano) ha comenzado recientemente la reforma de la legislación sobre los abogados. Por lo tanto, hay una oportunidad que la norma discriminatoria de la Constitución sobre el monopolio de los abogados para acudir a las cortes, resulte abolida. Por ello, se abre una vía para desarrollar el estatuto de las clínicas de derecho, donde los colaboradores de dichas instituciones tendrán la oportunidad, además de dar asesoría legal, de representar a sus clientes en las cortes.

Palabras clave: Derechos humanos, defensa legal, clínica de derecho, defensa jurídica básica, pro bono

Summary. I. Introduction. II. Methodology. III. Analysis of recent research. IV. History of the legal clinical movement. V. Legal Clinics In Ukraine. VI. The prospective of clinical movement as an essential part of human rights provision. VII. Conclusions. References.

\section{INTRODUCTION}

The Universal Declaration of Human Rights, adopted by the UN General Assembly on December 10, 1948, envisaged the equality of every person before the law. Besides, the declaration states that everyone has the 
right to protection against discrimination and also to the effective restoration of violated rights.

The state provides access for everyone to legal aid to effectively restore violated rights. Moreover, such access to legal aid should not depend on the financial status of the person in need of such aid.

Legal clinics of higher education institutions are an important subject of providing legal aid. Law clinics have many socially significant functions. The main function is to provide free legal aid to low-income citizens, as well as to develop students' practical skills, which they will need in their practical activity after graduation.

Clinical legal education provides law students with real-life work experience, develops local legal capacity, and helps to protect human rights around the world. Law clinics train lawyers and law students in the spirit of social justice and public service, and provide desperately needed legal services in underserved communities (Open Society Institute, 2009).

Grimes (1996), a well acknowledged author in this field, have tried to define a law clinic by suggesting that a law clinic is:

«A learning environment where students identify, research and apply knowledge in a setting which replicates, at least in part, the world where it is practiced. (...) It almost inevitably means that the student takes on some aspect of a case and conducts this as it would be conducted in the real world».

Moreover, according to Emil Winkler (2019), the emergence of clinical legal education begun in the United States, tightly followed by Canada, Australia and UK. When looking at the development historically it seems clear that it was two major forces that drove the development: an increasing need for legal aid and a need to reform the legal education and bring in a more practical approach to law practice.

Legal clinical movement is developed in many countries of the world. It is especially prevalent in the United States, where the participation of law school graduates is mandatory.

In Ukraine, the development of legal clinical activity began in the mid1990s. Nevertheless, the legal status of legal clinics in our country is still not properly enshrined in law. Accordingly, there is an urgent need to improve the current legislation of Ukraine in this field.

\section{Methodology}

Both general scientific and special methods of scientific research were used to achieve the goals of the article. 
First of all, the method of system analysis was used in the analysis of definitions and the legal framework in the field of legal clinical education. The historical method showed the historical aspects of the legal clinical movement.

Moreover, the methodological basis of the article was the dialectical method of cognition of social relations, phenomena and processes, which is to identify the peculiarities of the formation of the Institute of Legal Clinical Assistance. Due to the use of the comparative-legal method, it was possible to identify the peculiarities of the legal status of legal clinics in other countries.

The formal legal method was used in the analysis of the current legislation and in the development of recommendations for improving the legislation of Ukraine in the relevant field. A retrospective method helps to model the conclusions.

Also, the conclusions of the study are based on the analysis of the norms of the current legislation and practice of its application, court practice, and achievements of national legal science.

\section{ANALYSIS OF RECENT RESEARCH}

Scientists who have studied the legal status of legal clinics at different times have both domestic and foreign representatives. Among the domestic scholars who deal with these issues, it is worth mentioning Galai, Grechanyuk \& Sobol (2017), Dobrokhotova (2007), Elov (2004), Lodzuk (2013) and Savelova (2013).

Among foreign authors who are interested in legal clinical movement, it is worth noting Mkwebu (2014), Sameer M. Ashar (2012), Hubbard, Saladen, Tushaus \& Upreti (2019), Gupta \& Kapoor (2015), Grimes (1996) and Winkler (2019).

\section{HISTORY OF THE LEGAL CLINICAL MOVEMENT}

The term "legal clinic" first appeared in Professor George Frommgold's article "Juristische Kliniken", published in 1900 in the Federal Law Gazette. It is in this article that a German scientist suggested, similarly to clinics operating at medical faculties, to create clinics at law faculties where students, under the guidance of teachers, would not solve fictitious or outdated legal cases but "live" cases (Goncharenko, 2004). 
It should be noted that about half a century before the appearance of the article, Professor D. Meyer made an analogy between medical and legal practice and introduced special classes for students, during which they independently tried to "diagnose" and propose ways to "cure" a certain legal problem. Initially, such skills were imparted to students in ordinary audiences in civil law practitioners, but their development required the search for a different, more successful and closer to real professional practice form of study. Accordingly, in the mid-1940s, D. Meyer created the first organization, the prototype of a modern law clinic. However, the professor's initiative was not widely supported, the first "legal clinic" was closed and the professor's idea was forgotten.

Thus, the first law clinics, as a form of a combination of educational and practical purposes, emerged in the early twentieth century in Germany. However, the legal development of the "clinical movement" began in the mid-20th century in the United States.

In 1960, there were more than 30 law clinics in higher education in the United States, in which students, under the guidance of teachers and advocates, provided free legal assistance to low-income citizens (Polyakov, 2010). The first law clinics appeared in the structure of George Washington University and Columbia University (Kozenko, 2009).

Clinical programs have become widespread in the United States during the 1960s and 1970s. Moreover, the American Bar Association (ABA) suggested that law schools should consider legal clinical education as one of the methods for students to gain additional knowledge and practice.

In 1969, the Association published the "Standard Rules of Student Legal Practice", which are currently applied throughout the country. Under these rules, the purpose of student legal practice is to provide legal services to low-income clients and to encourage law faculties to expand the use of clinical education in order to provide students with advocacy skills (Elov, 2004).

At about the same time, legal clinical education is becoming widespread in other countries of the world, where special legal acts are adopted to ensure the proper functioning of legal clinics. For example, in 1968, Hungary amended certain sections of the Code of Criminal Procedure regarding the activities of legal clinics, under which students were granted the right to represent clients in court (Legal clinical education, 2019).

Legal clinics are available in Central and Western Europe, Central, South and East Asia, Latin America and Africa (Nechiporuk, 2008). With the help of the Rockefeller Foundation's support for the development of clinical education in 1978, the first law clinic was opened in South Africa, and since 1989, all law school graduates have been required to undergo 
practical training in a law clinic at the University of the Witwatersrand (Savelova, 2013).

Today, legal clinical education is developed in almost all regions of the world. In Europe, legal clinic representatives have even set up a joint organization called the European Network of Clinical Legal Education (ENCLE) (Stege, 2019). It is interesting that to coordinate the activity of legal clinics in our country, a public organization "Association of Legal Clinics" was created (Association of Legal Clinics of Ukraine, 2019).

Domestic and foreign scientific literature offers different wide-format and multi-vector approaches to the definition of particular types (classification) of legal clinics.

Molybogh distinguishes the following types of legal clinics: (i) classical law clinic - a program or institution created on the basis of a higher education institution for the practical training of law students and providing legal assistance to low-income persons (USA, Canada, Germany, Ukraine, etc.); (ii) Legal Aid Bureau-public funding legal clinics providing free legal aid to low-income citizens (the Netherlands); (iii) citizen advisory bureaus - government-run institutions providing legal information to each stakeholder (United Kingdom); (iv) legal waiting rooms - the Russian analogue of the classic law clinic, which focuses on providing legal assistance (Russian Federation); and, (v) a court-based law clinic at the department of a higher education institution - an institution in which the admission of citizens is carried out by senior students, simultaneously taking over the experience of both university teachers and professional judges (Russian Federation) (Yelov, Molybogh \& Pavlenko, 2004).

Depending on the ratio of influence on the work of the legal clinic of curators (teachers, lawyers) and students, this scientist distinguishes three relatively different models of legal clinics with the conventional names "student", "professional" and "universal". The Student Law Clinic provides for a greater degree of independence of students at the time of foundation and direct work, and its characteristic features are: (i) the main aim of the work of such an organization is students' education first of all; (ii) the possibility of full implementation of student initiative and enthusiasm; (iii) a sufficiently high level of professionalism of senior students; (iv) the possibility of more flexible search for financing; and, (v) low level of labor costs of full-time employees.

Establishment of a professional law clinic implies having a team of professional, paid supervisors working on a full-time basis: they read a clinical course, training, provide guidance and control of students. The characteristic features of such a clinic are: (i) qualitatively higher level of management training; (ii) the existence of guarantees of professional legal 
support for student advisers; (iii) much better financing conditions; (iv) guaranteed "patronage" of the educational institution; and, (v) close cooperation with independent organizations directly involved in the provision of legal services.

The Universal Law Clinic is a compromise between the first two models and involves balancing the role of students and curators in the activities of the law clinic, and its characteristic features are: (i) leadership is carried out jointly by students and faculty; (ii) under certain conditions, students can provide legal assistance more independently; (iii) close contacts are maintained with the management of the higher education institution; and, (iv) teachers within their competences are mainly engaged only in assisting students in their independent activity.

The authors of the Legal Clinic study guide divide legal clinics according to the methods of working with clients (those who work directly and those who do not work with clients), the order of creation and activity (created at a higher education institution and those working separately) as well as from specialization (specialized and non-specialized law clinics). At the same time, in the absence of any specialization, the work of a legal clinic is carried out in all areas of legal aid (Moldovan, \& Katsavets, 2007).

Galai (2013) considers it advisable to classify legal clinics by organizational form, by line of business and by their place in providing free legal aid. According to the organizational and legal form, this researcher identifies the following legal clinics: (i) structural unit of a higher education institution; (ii) public subdivision of higher education institution; (iii) organization of student initiative and self-government; (iv) a form of cooperation between a non-governmental human rights organization and a higher education institution; (v) temporary establishment of a specific project; (vi) other forms. According to the areas of activity, he proposes to separate the legal clinics into those that: (i) provide legal assistance; (ii) engage in legal education; (iii) work out imitation (modeling) of forms of practical work of a lawyer in the absence of visitors; and, (iv) have mixed forms. By methods of working with visitors-to legal clinics, which directly: (i) work with visitors; and, (ii) do not work with visitors. By way (place) of organization of rendering of legal aid-to legal clinics: (i) visiting (engaged in lectures, legal education through printed products, work under the program "Street law"); and, (ii) away or inpatient (legal clinics with separate premises, where they provide free legal aid).

This idea is shared by Dubchak (2012), who also proposes to separate legal clinics by forms of legal aid, types of legal services, and the time of operation of legal clinics and by type of founder. According to the forms of providing legal aid, this scientist considers it possible to divide legal clinics 
into those that provide: (i) primary legal aid; and, (ii) primary and secondary legal assistance. Moreover, according to specific types of legal services, this scholar divides legal clinics into those that: (i) provide only legal information, legal advice, and clarification; (ii) draw up documents of a legal nature; and, (iii) represent the interests of citizens. By time of operation-to legal clinics: (i) temporary; and, (ii) permanently operating. By type of founder-to law clinics established at (i) higher education institutions; and, (ii) public human rights organizations.

Some domestic scientists are considering the possibility of dividing legal clinics by the nature of their activity orientation: (i) externally oriented (such as society-oriented, providing free legal assistance to low-income groups, organizing law-enforcement activities, etc.); and, (ii) internally oriented (they are based only on the educational component of forming a student as a highly qualified specialist) (cfr. Sokolenko, 2009).

\section{LEGAL CLINICS IN UKRAINE}

As for Ukraine, legal clinical education in our country did not develop in the Soviet period, but having gained independence, our country began to make extensive use of this tool to improve the quality of legal education and to provide low-income clients with quality legal services.

The creation of proper conditions and procedures for the full and unrestricted realization of one's rights and legitimate institutional provision on human rights, including free legal assistance is one of the main directions of the state policy of Ukraine in the field of human rights.

The right to free legal aid is an opportunity guaranteed by the Constitution of Ukraine for an individual, regardless of citizenship, to receive fully free primary legal aid, as well as the possibility for certain categories of people to obtain free secondary legal aid in cases provided for by law.

In order to create an effective system of free legal aid, the Presidential Decree of June 9, 2006 approved the Concept of free legal aid in Ukraine aimed at the realization of human rights to justice in accordance with the Constitution of Ukraine (1996), the Convention for the Protection of Human Rights and Fundamental Freedoms (1950), the International Covenant on Civil and Political Rights (1966).

On June 2, 2011, the Verkhovna Rada of Ukraine adopted the Law on Free Legal Aid for the implementation of this concept executive authorities in the said sphere, the procedure for appealing against decisions, actions or inactivity of state authorities, local self-government bodies, their officials and officials on free legal aid. 
At the same time, defining the range of legal aid entities, the Ministry of Justice (the developer of the law) and the legislature did not take into account the real realities in the system of legal aid entities existing at the time of the adoption of this law, including the presence of a large number of legal clinics, created in most higher educational establishments of Ukraine, the experience of which fully confirms the possibility and necessity of their participation in this process (Yelov, 2019).

Legal clinics in independent Ukraine started to appear during 19961999 with the direct participation of youth, students and other public organizations (in the cities of Kyiv, Donetsk, Lviv, Odesa, Lutsk). Most sources state that the first law clinic in the Ukrainian state started operating in 1996 at Taras Shevchenko National University of Kyiv. According to other information, the first was the Law Clinic (Center of Practical Training) of Donetsk National University.

The activity of legal clinics in Ukraine in those years was not always supported by higher education institutions, as proponents of traditional academic education have long resisted such innovation. In view of this, most of the existing legal clinics were created on the sole initiative of the students, at the expense of grantors and non-governmental human rights organizations with an emphasis not on educational (practical) aspects, but on social ones (that is, in order to meet the needs of society in the field of law assistance and advocacy).

In 2003, the All-Ukrainian Congress of Educational Lawyers and Scholars "Conceptual principles of scientific and methodological provision of higher education Legal Education" (Odesa, October 24, 2003) noted the need to expand the experience of legal clinics for more a close link between students' theoretical background and practice as one of the priorities for the development of higher legal education and science of Ukraine. In turn participants of the All-Ukrainian conference "Forming and development of a network of legal clinics of Ukraine on the way to self-sufficiency" (Kyiv, November 14-16, 2013) discussed and approved draft Standards of Legal Clinics of Ukraine and the results All-Ukrainian Scientific-Practical Conference "Innovative Methods of Legal Education: Concept, Content and Practice of Application" (Kyiv, November 29, 2003). It was decided to apply to the All-Ukrainian Council for Legal Education and Science, Scientific and Methodological Council for Law of the Ministry of Education and Science of Ukraine, with a proposal to consider and approve these standards.

In this regard, as well as to preserve and further enhance the achievements of the legal clinical movement in 2003-2004 national network of legal clinics (18 legal clinics from fourteen regions of Ukraine) was united into the Association of Legal Clinics of Ukraine - an all-Ukrainian public 
organization, aimed at supporting the activities of legal clinics, promoting the development of legal clinical education and implementation relevant legal education and human rights programs (Lodzuk, 2015).

Now about 60 legal clinics are operating in Ukraine. The statistics of the Association of Legal Clinics shows, that according to the results of 2018, there are 48 legal clinics - members of the Association, involving more than 1600 students. The number of legal advice provided is approximately 14,000 , the number of procedural documents drawn up is approximately 3000 (Association of Legal Clinics of Ukraine, 2019).

A law clinic of the National University "Odesa Law Academy" was one of the first among legal clinics in Ukraine. Currently, more than 100 undergraduate and graduate students participate in its activities during the academic semester, and more than three hundred students from all faculties and institutes annually undergo educational (study), current and undergraduate (master's) internships (Lodzuk, 2015).

Back in 1998 (at the initiative of the National University "Odesa Law Academy" and representatives of the public organization "South Ukrainian Center for Young Lawyers") free legal consultation started its activity. Afterward, it was reorganized into a separate unit of the university - the legal clinic (Legal Clinic, 2019).

Today, the Law Clinic of the National University "Odesa Law Academy" provides free legal assistance to a wide range of individuals. Also, various educational activities are regularly held at the Law Clinic. Besides, (taking into account the current problems of today) Initiative Legal Assistance Groups for Persons Displaced from the Occupied Territories and Legal Assistance to Seafarers have been opened at the Law Clinic.

On average, the Law Clinic of National University "Odesa Law Academy" gives legal advice to 25-30 clients per week. During the year, the Legal Clinic provides approximately 6,200 consultations (Lomzec, 2018).

It should be noted that the legal clinics of higher educational establishments operate based on the Model Regulations on the Legal Clinic of Higher Educational Institutions, approved by the Ministry of Education and Science of Ukraine (in August 3, 2006, $\mathrm{n}^{\circ}$ 592). According to this provision, the Law Clinic is a structural unit of the higher education institution of the III-IV levels of accreditation, which prepares specialists in the field of "Law", and is created as a base for practical training and conduct of the educational practice of senior students.

In its activity, the legal clinic is guided by the legislation of Ukraine, the charter of the higher education institution and the Model Regulations on it, approved by the head of the educational institution. A legal clinic is not a legal entity. 
Under Ukrainian legislation the purpose of creating and operating of legal clinics is to achieve a number of social goals, among which are the following:

- improving the level of practical knowledge, skills and competences of law students; guarantee to every person, regardless of their financial status, the opportunity to receive quality legal assistance;

- formation of legal culture of citizens;

- preparing and educating students in a spirit of respect for and respect for the rule of law, justice, and human dignity;

- expanding the cooperation of higher education institutions providing training of legal professionals with the judicial, law enforcement, justice, state and local self-government bodies, with other institutions and organizations;

- introduction of elements of practical training of law students in the field of legal services in the educational process.

The main tasks of the law clinic are:

- providing students of the law clinic with the opportunity to acquire practical skills in the specialty;

- creating places for students to study and practice; providing citizens with free legal advice;

- conducting activities on legal education of the population;

- ensuring the possibility of communication of students during the educational process with experts-practitioners of the judicial and law enforcement bodies, other state bodies and local self-government bodies on the issues of their activity;

- creation of an effective mechanism for the exchange of information between the population, the media and the legal clinic, which will allow to respond promptly to the practical needs of citizens.

Even though legal clinics provide primary legal aid that complies with the features provided by the Law of Ukraine "On Free Legal Aid" of June 2, 2011 (On Free Legal Aid: Law of Ukraine, 2011), they are not included in the list of subjects providing primary legal aid.

\section{THE PROSPECTIVE OF CLINICAL MOVEMENT AS AN ESSENTIAL PART OF HUMAN RIGHTS PROVISION}

In order to determine the legal status of legal clinics and the basic principles of their activity, a draft law "On Amendments to Certain Legislative Acts of Ukraine (regarding the definition of the status of legal clinics as subjects of provision of free primary and secondary legal aid)" was 
outlined on December 12, 2012, $\mathrm{n}^{\circ} 926$ (Draft Law on Amendments to Certain Legislative Acts of Ukraine, 2019).

One of the most important proposals that were reflected in the said draft law was the listing of legal clinics in the list of entities providing primary and secondary legal aid under articles 9 and 15 of the Law (On Free Legal Aid: Law of Ukraine, 2011). Thus, the legal status of legal clinics of higher education institutions would be recognized at the level of the law, not by-law. In addition, basic principles of functioning of legal clinics would be defined at the law level.

Besides, according to the draft law, it was necessary to define the peculiarities of legal clinics among other divisions of legal higher educational establishments of Ukraine, to consolidate the functions of legal clinics as additional tools for practical training of students, as well as to provide free legal aid to wider layers of the population.

The draft law also provided the norm, according to which legal clinics interact with the centers for the provision of secondary legal aid, with the courts, prosecutor's offices, and other law enforcement agencies, executive authorities, local authorities.

According to the drafters of the bill, legal clinics should not have the status of a legal entity but should function in the structure and at the expense of higher education institutions. However, the possibility of co-financing legal clinics, which can be provided by universities, local communities, and the state at the expense of appropriate budget levels, is not excluded.

Regarding the free legal aid provided in a legal clinic, it should be provided to students of higher education institutions under the supervision of supervisors who have a law degree and relevant professional experience of at least 2 years and are responsible for educational practice.

The format of the work of a legal clinic should provide for the continuity of legal assistance. Services provided to students by visitors include the provision of general legal advice and clarification, the submission of applications, complaints and other documents, assistance in providing a person with access to secondary legal assistance, and mediation.

The draft law proposed to set clear deadlines for legal clinic representatives to respond to requests. Such time limits shall be at least 15 calendar days from the date of receipt of the request from the person requiring free primary legal aid.

In addition to primary legal aid, the draft law also provided for the possibility of giving legal clinics the right to exercise representative functions in the courts (secondary legal aid). Persons who would serve as representatives in court should have a law degree, and in that case, students would only assist such persons in the exercise of those functions. 
However, despite the need to improve the legal status of legal clinics, the Parliament of Ukraine has not adopted the proposed draft law.

Moreover, the recently introduced advocacy reform has narrowed the capacity of legal clinics to provide legal assistance and has even made access to legal aid for low-income citizens difficult.

Thus, while domestic law formally guarantees access to legal aid for every person, in reality, it is not.

Art. 59 of the Constitution of Ukraine (1996) states that everyone has the right to professional legal assistance. Besides, that article expressly provides that in certain cases such assistance is free of charge. However, by 2016, the norm of Art. 59 of the Constitution provided another wording:

«Everyone has the right to legal assistance. In the cases provided for by law, this assistance is provided free of charge. Everyone is free to choose the defender of his or her rights. To ensure the right to defense against prosecution and to provide legal assistance in the resolution of cases in courts and other state bodies in Ukraine, there is a lawyer's office» (Article 59 of the Constitution of Ukraine, 2013).

As we can see, in 2016 the term was changed from "legal aid" to "professional legal aid". This took place within the framework of the adoption of the so-called "lawyer monopoly", that is, the prohibition to perform representative functions in courts for a wide range of legal representatives and to grant such a right solely by a lawyer.

In order to clarify the term "professional legal assistance", the text of the Constitution (1996) has been supplemented by Article 131-2, which stipulates that only lawyers can provide professional legal assistance.

At the same time, other professional lawyers (persons with a law degree, as well as any other persons with sufficient level of knowledge and skills to represent others in court) were eliminated from the opportunity to participate in litigation. Thus, in fact, the state has narrowed down the subjective composition of persons who could provide legal assistance to those who need it, at least in the part of the judicial representation.

Supporters of the advocates' (attorneys') monopoly have their arguments in favor of their position, and opponents their own. Arguments for the advocates' monopoly are: (i) such a monopoly is found in most developed countries, in particular in the European Union; (ii) the monopoly of advocates at law is similar to that of notaries or doctors; (iii) advocates' monopoly on representation will promote the establishment of a single corporation; and, (iv) advocates' monopoly is a guarantee of the citizens' realization of the constitutional right to qualified legal aid (better quality, with the possibility of complaining about unethical behavior). 
Arguments against advocates' monopoly are: (i) obtaining an advocate's status will inevitably be associated with the complexities and corruptive components; (ii) monopoly is contrary to the rule of law, access to justice is impeded; (iii) monopoly does not correspond to the level of development of society in the country and is similar to a closed club, so it may not positively affect the development of competition (the lower the competition, the lower the quality); (iv) recourse to attorneys for small claims is unjustified; (v) attorneys will be controlled by the state; and, (v) the shortage of lawyers in small cities will make it impossible to exercise the right to legal aid.

Indeed, exclusive representation of clients' in courts by attorneys is active in the vast majority of European countries and in the United States. In Turkey, Spain, Italy and Germany, only legal attorney operates at all levels of the judicial representation. Among the 48 countries in Europe, 33 have a advocates' monopoly to protect the accused person, and in 22 , also to represent the interests of the victim. In civil matters, lawyers have a monopoly in 18 European countries. In administrative law, an advocates' monopoly exists in 14 European countries.

In many European countries, the exclusive right of attorneys to represent their clients in courts has been exercised for many years. For example, in Germany and Austria, where the level of professionalism of attorneys is one of the highest, the state policy of introducing an advocates' monopoly was started about 50 years ago.

At the same time the model of such monopoly, chosen in Ukraine discriminates the rights of persons and legal entities.

It seems that advocates' monopoly narrows the content and scope of the existing rights in the Constitution (1996), as enshrined in Article 59. The exclusive right of attorneys for the representation of clients in the courts complicates the access of people to justice. Besides, the lack of competition may prevent the bar from normal development.

However, this year, at the initiative of the President of Ukraine, the process of abolishing the lawyer's monopoly on representation in court began. In particular, on October 17, 2019, the Grand Chamber of the Constitutional Court of Ukraine recognized constitutional bill $n^{\circ} 1013$ on the abolition of the lawyer's monopoly (the Court of Cassation of Ukraine declared the bill abolishing the lawyer's monopoly constitutional, 2019).

The Constitutional Court admitted, that the notion of "professional legal assistance" is not the same as the term "representation of a person in court". Attorneys provide professional legal assistance; instead, representation of a person in court may be made at the discretion of a lawyer or other entity. 
The Parliament can now pre-approve this bill with 226 votes, that is, adopt it in the first reading. The Parliament may then consider it for adoption at the next ordinary session. This will require at least 300 votes from parliamentarians.

\section{Conclusions}

This research allows us to draw the following conclusions:

1. Therefore, the role of legal clinics in today's context is difficult to overestimate. On the one hand, they perform an important educational function and, on the other, an equally important social function. A student involved in a law clinic activity receives invaluable practical knowledge, skills, and abilities, and a law clinic client receives quality free legal assistance.

2. The Legal Clinical Movement originated in Western Europe, developed in the United States and has now spread to most regions of the world. Our country does not stand aside from these processes. In particular, in Ukraine, all leading higher education law schools opened their own legal clinics. However, in order to maximize the benefits of legal clinics in our country, it is necessary to make some changes to the current legislation.

In particular, legal clinics should be included in the list of entities providing primary legal aid, which is contained in the basic law on legal aid.

3. As for secondary legal aid, unfortunately, domestic law clinics in institutions of higher education are currently allowed to provide primary legal assistance only, meaning that they are deprived of the opportunity, like any other legal practitioner, to assist their clients in litigation. At present, attorneys are solely entitled to this right.

On the other hand, if People's Deputies in the nearest future will overcome the complicated procedure of approving a bill amending the Constitution of Ukraine, the "attorneys' monopoly" will be abolished. This move will increase the authority of legal clinics in the process of providing legal aid and, in general, will increase the access of all segments of the population to quality legal aid. 


\section{REFERENCES}

Ashar, S. M. (2012). The Global Clinical Movement: Educating Lawyers for Social Justice. Journal of Legal Education, 62, 193-205. Retrieved from https://papers.ssrn. com/sol3/papers.cfm?abstract_id=2141470 (8-XII-2019).

Association of Legal Clinics of Ukraine. (2019). Retrieved from https://legalclinics.in.ua/ (8-XII-2019).

Convention for the Protection of Human Rights and Fundamental Freedoms as amended by Protocols $\mathrm{n}^{\circ} 11$ and 14. (1950).

Dobrokhotova, O.M. (2007). Practical training of lawyers in Russia: the history of formation and development prospects. Saint Petersburg.

Dubchak, N.S. (2012). Classification of legal clinics: a theoretical analysis. Bulletin of the Academy of Advocacy of Ukraine, 25(3), 198-200.

Elov, V. (2004). When will the university train lawyers rather than "graduates"? Law of Ukraine, 1, 132-135.

Galai, A. O. (2013). Legal clinic as a subject of administrative legal relations. Bulletin of the Ministry of Justice of Ukraine, 138(4), 66-73.

Galai, A. O., Grechanyuk, S. K., \& Sobol, E. Y. (2017). Street law from law clinics as an effective informal legal education program for teens. Science and education, 4 , 20-28. Retrieved from http://nbuv.gov.ua/UJRN/NiO_2017_4_6 (8-XII-2019).

Goncharenko, V.O. (2004). Legal Clinic. History and definitions. Practice of Legal Clinics of Ukraine, 1, 3-5.

Grimes, R. (1996). The Theory and Practice of Clinical Legal Education. In Effective Learning and Teaching in Law, R. Burridge et al. (eds.), Kogan.

Hubbard, B., Saladen, M., Tushaus, D. W. \& Upreti, N. K. (2019). Taking justice to people in crisis: Mobile legal clinics. Alternative Law Journal, 44(1), 76-81. DOI 10.1177/1037969X19829550.

International Covenant on Civil and Political Rights (1966). The Office of the High Commissioner for Human Rights (UN Human Rights).

JuristOFF (2013). Article 59 of the Constitution of Ukraine 2013: Articles of the Constitution of Ukraine. Retrieved from https://juristoff.com/resyrsi/kz/ konstitutsiya-ukrajini/rozdil-2-prava-svobodi-ta-obov-yazki-lyudini-igromadyanina/11012-stattya-59-konstituciya-ukrajini-2013-statti-konstitucijiukrajini (8-XII-2019).

Kozenko, Y. (2009). Law clinics: learning by helping. Law Student, 6(5), 22-23.

Legal Clinic. (2019). National University "Odessa Law Academy”. Retrieved from http://onua.edu.ua/index.php?option=com_content\&view=article\&id=734\&Ite mid=391\&lang=uk (8-XII-2019).

Legal clinical education. (2019). Law Clinic. Retrieved from http://clinic.lawinstitut.ru/ru/about/ (8-XII-2019). 
Lodzuk, M. (2015). Law clinics in Ukraine: education and legal assistance. Odessa: Phoenix. Retrieved from https://legalclinics.in.ua/wp-content/uploads/ Lodzhuk_monografiya.pdf (8-XII-2019).

Lodzuk, M.T. (2013). The system of legal aid in the Russian Federation: the activity of legal clinics. Actual problems of legal science. Research Practice Conf. "Twelve Autumn Legal Readings." Khmelnytskyi: Khmelnitskyi University of Management and Law.

Lomzec, Y. (2018). Results of monitoring of the Law Clinic of the National University of Odessa Law Academy. Odessa: Association of Legal Clinics of Ukraine. Retrieved from https://legalclinics.in.ua/wp-content/uploads/Zvit-OdesaNYUA-2018.pdf (8-XII-2019).

Mkwebu, T. (2014). The Global Clinical Movement: Educating Lawyers for Social Justice. International Journal of Clinical Legal Education, 21, 289-302. Retrieved from https://www.researchgate.net/publication/314550415_THE_GLOBAL_CLINIC AL_MOVEMENT_EDUCATING_LAWYERS_FOR_SOCIAL_JUSTICE (8XII-2019).

Moldovan, V.V., \& Katsavets, P.C. (2007). Legal Clinic. Kyiv: Center for Educational Literature.

Nechiporuk, S. (2008). History of law clinic. Khreshchatyk, 177, 16-19.

On Free Legal Aid: Law of Ukraine. (2011). Verkhovna Rada (Ukrainian Parliament). Retrieved from https://zakon.rada.gov.ua/laws/show/3460-17 (8-XII-2019).

Open Society Institute (2009). Legal Clinics. Hungary: Createch Ltd. Retrieved from https://www.justiceinitiative.org/uploads/0763f81d-04c4-4f72-bd8867f6ee89dd69/legalclinics_20090101.pdf (8-XII-2019).

Polyakov, M.B. (2010). The history of legal clinics and clinical legal education. Russian Law Journal, 2, 6-68. Retrieved from https://cyberleninka.ru/article/n/istoriyavozniknoveniya-yuridicheskih-klinik-i-klinicheskogo-yuridicheskogoobrazovaniya (8-XII-2019).

Savelova, Y. M. (2013). The historical and legal aspect of the emergence and development of legal clinical education. Small and Medium Business (Law, State Economy), $1,37-41$.

Sokolenko, O.L. (2009). Legal clinic in legal education. Bulletin of the Academy of Customs Service of Ukraine, 2(1), 40-44.

Stege, U. (2019). Legal clinical education for the benefit of asylum seekers, refugees and migrants in Europe. Legal dialogue. Retrieved from https://legaldialogue.org/ru/mezhdunarodny-symposium-2018/interview-intro (8-XII-2019).

The Court of Cassation of Ukraine declared the bill abolishing the lawyer's monopoly constitutional. (2019). Ukrinform. Retrieved from https://www.ukrinform.ua/ rubric-polytics/2810381-ksu-viznav-zakonoproekt-pro-skasuvannaadvokatskoi-monopolii-konstitucijnim.html (8-XII-2019). 
Tushaus, D. W., Gupta, S. K., \& Kapoor, S. (2015). India Legal Aid Clinics: Creating Service Learning Research Projects to Study Social Justice. Asian Journal of Legal Education, 2(2), 100-118. DOI 10.1177/2322005815578509

Ukraine (1996). Constitution of Ukraine. Retrieved from https://zakon.rada.gov.ua/ laws/show/254\%D0\%BA/96-\%D0\%B2\%D1\%80 (8-XII-2019).

Ukraine (2019). Draft Law on Amendments to Certain Legislative Acts of Ukraine (concerning the definition of the status of legal clinics as entities providing free legal aid). Retrieved from http://w1.c1.rada.gov.ua/pls/zweb2/webproc4_2? pf3516=9502\&skl=7 (8-XII-2019).

Winkler, E. (2019). Clinical Legal Education: A report on the concept of law clinics. Retrieved from https://law.handels.gu.se/digitalAssets/1500/1500268_lawclinic-rapport.pdf (8-XII-2019).

Yelov, V. (2019). Location of Legal Clinics in the System of Free Legal Assistance, Their Role and Importance in the Reform of Higher Legal Education. Law online. Retrieved from http://www.pravoonline.org.ua/site/kbase/c/39/category/korisnainformaciya-dlya-pravnikiv/t/83/title/misce-yuridichnih-klinik-v-sistemibezoplatnoyi-pravovoyi-do\# (8-XII-2019).

Yelov, V. A., Molybogh, S.I., \& Pavlenko, D.G. (2004). Legal Clinic. Kyiv: Schoolboy. 